\title{
A piedade e a força: o trabalho forçado em obras de socorros públicos nas secas da passagem do século XIX
}

\author{
Tyrone Apollo Pontes Cândido*
}

Resumo: Neste artigo procuro enfrentar o problema de caracterizar como forçado o trabalho executado pelos retirantes das secas no território semiárido brasileiro (em particular no Ceará) durante a passagem do século XIX e, com base nessa experiência, refletir o sobre a pertinência de se considerar a presença de relações não livres de trabalho no contexto da chamada "transição para o trabalho livre", ainda quando os sujeitos sociais em pauta não tenham sido trabalhadores escravos.

Palavras-chave: trabalho forçado; obras de socorros públicos; “transição para o trabalho livre".

Abstract: This article aims to face the problem of characterizing as forced the labor performed by drought migrants of Brazilian semi-arid territory (particularly in Ceará) during the late nineteenth century and, based on that experience, reflect about the relevance of considering the presence of non-free labor relations in the context of "transition to free labor", even when social actors on the agenda were not slave laborers.

Keyworkds: forced labor; relief works; "transition to free labor".

\section{Secas e relações de trabalho no universo sertanejo}

Não é difícil encontrar características de trabalho forçado e degradante no cotidiano dos retirantes das secas engajados em obras de socorros públicos, como foram construções de estradas de ferro, de rodagem, açudes de diferentes

* Doutor em História pela Universidade Federal do Ceará (UFC). Professor do Curso de História da Universidade Estadual do Ceará (UECE), Campus de Quixadá, e do Mestrado Interdisciplinar em História e Letras na mesma instituição. Este artigo é fruto de pesquisa que desenvolvi durante meu doutorado na UFC e que contou com financiamento através de bolsa da FUNCAP. Agradeço aos pareceristas da Revista Mundos do Trabalho por preciosas considerações que me ajudaram a melhorar o presente artigo. 
dimensões, portos, reformas urbanas de diversos tipos e um sem-número de outras atividades organizadas no Ceará e em outras províncias (em seguida, estados da federação) situadas no que se convencionou chamar de Nordeste durante a passagem do século XIX. ${ }^{1}$ Engenheiros autoritários, grupos de operários controlados pela presença de feitores, o serviço executado em troca basicamente de comida nos tempos de maior restrição, a presença de policiais armados inibindo brigas e revoltas, a distribuição de rações estragadas, a acumulação de dívidas com os fornecedores, a exposição dos trabalhadores a condições perigosas, episódios de castigos corporais, além das humilhações com que os administradores subjugavam os retirantes - ainda que não unicamente dessas maneiras - compunham um cenário comum das obras públicas às quais os sertanejos pobres viam-se levados a se engajar por força do contexto de calamidade, mas com o qual souberam aprender a lidar, criando formas de resistência, tornando as jornadas de trabalho um cotidiano conflitivo.

O foco deste artigo está voltado para as experiências de trabalho de milhares de sertanejos pobres do Ceará e províncias adjacentes que, nos tempos de estiagem prolongada, entre as décadas finais do século XIX e as primeiras do século XX, eram recrutados para obras de socorros acionadas pelos poderes públicos, visando conter o que era visto como uma desordem crescente provocada pelos pobres dos sertões. Esses novos operários eram homens e mulheres de todas as idades, pessoas originadas das mais diversas ocupações características do universo sertanejo e que, por ocasião dos tempos de estiagem, tornavam-se multidões de retirantes concentradas em vilas, cidades e outros centros populacionais. Tratavase assim de pessoas livres que viveram entre os anos finais do regime escravista e pós-abolição e que, durante os tempos difíceis das secas, foram levadas a contrair relações de trabalho assalariadas, cujo regime produtivo era de tal forma pesado e degradante que lhes parecia em muito assemelhar ao trabalho exercido pelos escravos.

Os anos de secas tornavam-se momentos propícios à difusão de relações de trabalho assalariadas numa ordem social em que os sertanejos mais pobres costumavam rejeitar o assalariamento como uma modalidade de trabalho indigna e indesejada porque vinha substituir meios de vida considerados mais autônomos, nas quais se preservava de alguma forma possibilidades de o trabalhador manterse, a si e a sua família, em certo patamar de segurança alimentar aceitável. Era o caso dos agricultores que viviam de seus roçados em terras próprias ou sob a condição de moradores de grandes propriedades. Também de vaqueiros e outros profissionais que podiam gozar de relativo controle sobre o modus operandi na criação do gado em face de fazendeiros absenteístas. Thomas Pompeu de Souza Brasil, senador do Império que se dedicou a escrever em seu Ensaio estatístico da província do Ceará (1864) sobre as formas de sustento dessas maiorias do sertão seco, afirmou em meados daquele século:

A caça de animais, de tubérculos silvestres, bem como do mel de abeIhas é nos anos secos, e mesmo ordinariamente, o recurso poderoso das classes pobres do interior. Numerosas famílias pelo sertão não têm outro meio de vida. É sobretudo notável nessa indústria primitiva a caçada das rolas de arribação, chamadas pombas de bando, que por todo

1 A denominação “Nordeste” para a região do semiárido brasileiro foi uma construção histórica que aparece particularmente atrelada aos discursos sobre as secas no início da década de 1920, como mostrou ALBUQUERQUE JR., Durval Muniz de. "Falas de angústia e de astúcia: a seca no imaginário nordestino - de problema a solução (1877-1922)”. (Dissertação de Mestrado em História, Universidade Estadual de Campinas, 1988.) 
sertão apanham-se por milhões na ocasião do pouso, bebida e postura. Secam e conduzem em cargas para as serras, ou vendem ou trocam por farinha, rapadura, legumes, etc. ${ }^{2}$

Não há na fala do senador Pompeu referências a proprietários ou patrões, pois enfoca empreendimentos cuja iniciativa era atribuição das próprias comunidades sertanejas. Trata-se de uma gente muito pobre, decerto, mas ciosa por preservar em seu modo de vida aquele espaço de autonomia encarado como o sinal distintivo de sua liberdade. ${ }^{3}$

Muitos eram obrigados eventualmente a sair pelas planuras sertanejas oferecendo seus serviços de "foice e machado" quando não encontravam outra saída para sustentar a família. Mas numa província em que a colonização se dera sob o pesado jugo das "guerras de corso" (nas quais tribos indígenas eram dizimadas, restando mulheres e crianças cativadas como prêmio aos vencedores), em que o tráfico para o sul do país multiplicava os casos de famílias de escravizados separadas compulsoriamente, em que jovens do povo eram recrutados à força e em larga escala para o serviço militar (como punição contra suas veleidades de querer fazer uma vida independente dos poderes locais), o trabalho vinculado à autoridade de proprietários rurais mais ricos era muitas vezes encarado como uma forma a mais de cativeiro a aprisionar as camadas pobres mestiças. Buscando estar sob o mesmo ponto de vista dessa mentalidade popular desconfiada, o poeta Juvenal Galeno registrou em seus versos:

\author{
Bem a Joana me dizia \\ Nas horas da privação: \\ - Homem, faz um roçadinho, \\ Planta arroz, planta feijão, \\ Que esta vida de alugado \\ Ao pobre não serve, não!4
}

Ao longo do século XIX, diversas medidas de controle social (como a formação de algumas Companhias de Trabalhadores por iniciativa do governo provincial ou a ação do recrutamento militar forçado na perseguição ao "crime"

2 Sobre as mudanças nos modos de vida de sertanejos pobres ao longo do século XIX, cf. NEVES, Frederico de Castro. “A Lei de Terras e a Lei da Vida: transformações no mundo rural do Ceará no século XIX”. Estudos de História, Franca-SP, v.8, n.2, p.37-58, 2001. SANTOS, Martha S. "Honra, terra e violência: o mundo dos homens pobres livres do sertão cearense do século XIX”. Trajetos - Revista de História UFC, Fortaleza, v.6, n.11, p.9-22, 2008. BRASIL, Tomás Pompeu de Souza. Ensaio estatístico da província do Ceará. Tomo 1. Edição fac-similar. Fortaleza: Fundação Waldemar Alcântara, 1997, p.347.

3 Não houve no Ceará a implantação de um regime escravista tão intenso quanto em outras diversas regiões do Brasil, o que não significa, por outro lado, que não tenha havido uma presença significativa de escravos africanos difundida por toda a sociedade. Essa característica socioeconômica deve ter influenciado de um modo particular a consciência social das camadas pobres em relação aos significados atribuídos às noções de cativeiro e liberdade. Sobre a presença de escravos na sociedade cearense: FUNES, Eurípedes. "Negros no Ceará”. In: SOUZA, Simone de (Org.). Uma nova história do Ceará. $4^{\text {a }}$ ed. Fortaleza: Edições Demócrito Rocha, 2007, p.103-132.

4 PINHEIRO, Francisco José. "Mundos em confronto: povos nativos e europeus na disputa pelo território". In: SOUZA, Simone de (Org.). Uma nova história do Ceará. $4^{a}$ ed. Fortaleza: Edições Demócrito Rocha, 2007, p.17-55. FERREIRA SOBRINHO, José Hilário. "Catirina, minha nêga, tão querendo te vendê": escravidão, tráfico e negócios no Ceará do século XIX. Fortaleza: SECULT/CE, 2011. RAMOS, Xisley de Araújo. "Por trás de toda fuga nem sempre há um crime: recrutamento "a laço" e os limites da ordem no Ceará (18501875)". (Dissertação de Mestrado em História Social. Fortaleza: UFC, 2003). GALENO, Juvenal. Lendas e canções populares. $4^{\mathrm{a}}$ ed. Fortaleza: Casa de Juvenal Galeno, 1978, p.57. 
e à "vadiagem") contribuíram para promover a proletarização de parcelas crescentes da população sertaneja no Ceará, mas o alcance dessas mudanças foi sempre bastante limitado em função da ausência de um corpo de agentes estatais (engenheiros, juízes, delegados, policiais) capaz de interferir de forma eficaz no sentido de "modernizar" as relações de trabalho tradicionais. O sertão mantinha-se, a despeito das mudanças, um espaço dominado pelo arcaísmo, governado por poderosas famílias de proprietários, senhores de terras, de animais e de pessoas. ${ }^{5}$

As secas eram, nesse sentido, momentos privilegiados para que frações das elites mais afinadas com os interesses modernizadores (em geral, comerciantes, financistas, proprietários rurais esclarecidos, jornalistas, engenheiros e outros profissionais liberais) fizessem implantar seus projetos reformadores (que vinculavam à ideia de "progresso"), aproveitando a presença de milhares de pessoas desempregadas e cujas plantações de subsistência e pequenos criatórios de animais encontravam-se arruinados pela falta de água. Inúmeras obras eram então acionadas com verbas provenientes de doações particulares ou do auxílio oficial do governo, promovendo os assim chamados "melhoramentos materiais": ferrovias, estradas, portos, reservatórios de água, calçamentos de ruas e praças, pontes, prédios para o funcionamento de escolas, igrejas, cadeias, etc. As comissões de socorros públicos (constituídas durante as secas por autoridades locais de vilas e cidades que exerciam cargos de vereadores, médicos, juízes, alguns padres, entre outros profissionais de prestígio) tratavam de organizar os retirantes no sentido de selecionar "emigrantes válidos" para os trabalhos executados nas localidades do sertão ou nas cidades do litoral (para onde iam a maioria dos flagelados), criando a modalidade do "socorro indireto", destinado àqueles que deveriam retribuir com a prestação de trabalho os auxílios oferecidos pelos comissários. O plano era de que apenas crianças de tenra idade, pessoas muito velhas, doentes e famintos invalidados para as prestações de serviços ganhassem os socorros gratuitamente. ${ }^{6}$

A política de socorrer os retirantes com trabalho assalariado era informada e reforçada pela ideologia liberal prevalecente que acreditava que a distribuição gratuita de comida e roupas terminaria por fomentar os considerados "vícios da vadiagem", estimulando a prática da mendicidade entre os sertanejos. A multiplicação de casos de saques a depósitos de alimentos, assaltos em estradas, conflitos envolvendo retirantes e policiais nas ruas das principais cidades, além do crescimento assustador de casos de doenças infectocontagiosas entre os miseráveis (gerando epidemias que chegavam a contaminar membros das elites urbanas), tudo isso se dando num quadro de aglomeração de dezenas de milhares de retirantes concentrados em abarracamentos considerados fétidos e de difícil vigilância pelos agentes das comissões de socorros, parecia endossar as teses de que os sertanejos constituíam uma espécie de "classe perigosa" a ser urgentemente controlada para que não terminassem por se constituir em real ameaça à civilização. Sobre esse pano de fundo ergueu-se a medida de, por meio do assalariamento,

5 Sobre o processo de proletarização dos sertanejos: CÂNDIDO, Tyrone Apollo Pontes. "Sertão proletário: pobreza, paternalismo e trabalho no Ceará oitocentista". Saeculum - Revista de História (UFPB), João Pessoa, n.33, p.163-182, jul./dez. 2015.

6 Pode-se acompanhar a dinâmica da política do "socorro indireto" aos retirantes lendo as falas e relatórios de presidentes de província e de Estado dos anos de seca. Um bom exemplo é a fala do presidente José Júlio de Albuquerque Barros para o ano de 1878: CEARÁ. Fala com que o Exmo. Sr. José Júlio de Albuquerque Barros, presidente da província do Ceará, abriu a $1^{a}$ sessão da $24^{a}$ legislatura da Assembleia Provincial no dia $1^{\circ}$ de novembro de 1878. Fortaleza: Typographia Brazileira, 1879. 
transformar os retirantes "de mendigos em trabalhadores", ainda que houvesse de se valer de meios coercitivos para se chegar a esse objetivo.?

As grandes secas da passagem do século XIX - em 1877-79, 1888-89, 1900, 1915 e 1919 - delinearam, portanto, um tempo de significativas mudanças para uma maioria das populações sertanejas. A cada ano em que uma nova seca era declarada, milhares de famílias deixavam seus povoados do sertão. Uma quantidade nada insignificante, ao chegar ao litoral, prolongava a retirada, embarcando em vapores lotados à procura de alternativas de vida em outras províncias, nas quais imaginavam não ter mais de enfrentar tempos de seca. Muitos, no entanto, encontravam seus últimos dias nessa emigração. Morriam em massa em embarcações superlotadas, subalimentados e adoecidos. Por cafezais, seringais, colônias agrícolas, construções de estradas e ferrovias, ou fosse lá qual outro tipo de empreendimento em que viriam a se engajar pelo país afora, apenas uma minoria conseguia a ascensão social almejada. No mais das vezes, encontravam alhures novas condições de trabalho, às quais os retirantes rapidamente associavam à velha opressão e à miséria, despertando então o desejo de voltar para sua terra. Os desdobramentos dessa grande diáspora ultrapassaram gerações, estabelecendo rotas percorridas por trabalhadores cearenses em todas as direções até os dias atuais, fazendo dos sertanejos do Ceará uma das parcelas mais móveis da população brasileira. ${ }^{8}$

No entanto, a maioria dos retirantes permanecia no Ceará durante os meses em que se alongavam as secas. Optavam por ficar sob os cuidados das diversas comissões de socorros públicos estabelecidas nos pontos de maior concentração de imigrantes. Chegavam com suas famílias, às vezes em grupos bem maiores, engrossados por novos indivíduos que iam aderindo aos peregrinos da fome. Constituíam uma multidão heterogênea, formada por gente dos mais diversos recantos do interior, de todas as idades, lavradores e criadores, jornaleiros e artífices, indígenas e criadas domésticas, curandeiros e assaltantes, eventualmente escravos fugidos tentando se esconder na aglomeração humana, havendo também pessoas remediadas ou mesmo médios e grandes proprietários "habituados a comer em pratos de porcelana e a beber em copos de prata!", mas que nos tempos difíceis das secas viam-se nivelados na ruína aos mais pobres dos pobres. As comissões de socorros tratavam de organizar aqueles considerados válidos para o trabalho em turmas de operários. Sob a gerência de feitores e chefes de turma, trabalhavam segundo jornadas definidas por engenheiros e mestres de ofício, executando geralmente atividades das mais simplórias, como o carregamento de pedras ou deslocamento de terra... No cotidiano das obras de socorros públicos, os retirantes aprendiam a lidar com novos códigos de produção, enfrentando um controle mais estrito de uma divisão social do trabalho diversa daquela a que estavam habituados. Alguns aprendiam mesmo os segredos dos ofícios de carpintaria, serralheria, cantaria. Com o passar do tempo, e a cada nova seca, o trabalho nas turmas de operários das obras de socorros públicos passava a figurar no horizonte de expectativas dessas multidões de sertanejos. Era o contorno histórico da formação dos proletários das secas se definindo. ${ }^{9}$

7 NEVES, Frederico de Castro. “'Desbriamento' e 'perversão': olhares ilustrados sobre os retirantes da seca de 1877". Projeto História, São Paulo, v.27, p.167-189, 2003. CHAVES, José Olivenor Souza. "Fortaleza e os retirantes da seca de 1877-79”. (Dissertação de Mestrado em História. Recife: UFPE, 1995).

8 MORAIS, Viviane Lima de. "Razões e destinos da migração: trabalhadores e emigrantes cearenses pelo Brasil no final do século XIX”. (Dissertação de Mestrado em História Social. São Paulo: PUC/SP, 2003). BARBOZA, Edson Holanda Lima. "A hidra cearense: rotas de retirantes e escravizados entre o Ceará e as fronteiras do Norte (1877-1884)”. (Tese de Doutorado em História Social. São Paulo: PUC/SP, 2013).

9 CÂNDIDO, Tyrone Apollo Pontes. "Proletários das secas: arranjos e desarranjos nas fronteiras do trabalho 
Tomando por base a correspondência trocada entre engenheiros, comissários de socorros públicos, autoridades locais e nacionais, alguns títulos da imprensa cearense do período, além de passagens de textos literários, registros de cronistas e ainda uma fotografia enquadrando uma turma de operários em atividade de construção de linha férrea, este artigo apresenta aspectos do cotidiano de trabalho dos retirantes nas obras de socorros públicos, problematizando especialmente os aspectos coercitivos dessas experiências. Em sua última parte, o artigo apresenta uma discussão a respeito de como relações de trabalho como essas, presentes em obras de socorros públicos dos tempos de seca, contradizem uma narrativa histórica que via nas décadas da passagem do século XIX para o XX uma "transição para o trabalho livre" no país, sugerindo em alternativa uma abordagem da história social que considere outras modalidades de trabalho compulsório, para além do trabalho escravo.

\section{O uso da força}

Muitas evidências indicam que os retirantes estranhavam, desde mesmo os primeiros contatos com as obras de socorros públicos, a natureza e a condução dos trabalhos demandados nos canteiros. Além de muitas tarefas divergirem daquelas que costumavam haver na lida diária da plantação ou da criação de gado, os métodos racionalizados de cumprimento dos serviços (com metas de produção estabelecidas e horários cronometrados, típicos dos modelos capitalistas de trabalho) contrastavam aos modos usuais dos sertanejos trabalharem. Nas obras de socorros públicos, os retirantes eram organizados em turmas de trabalhadores, lideradas por feitores que, por sua vez, estavam submetidos às ordens de chefes de turmas e, acima destes, de engenheiros, numa ordem hierárquica inexistente no labor tradicional. A ordenação dos retirantes em trabalhos extenuantes e sob ritmo contínuo de produção chocava-se com os hábitos laborais dos sertanejos. Uma coisa era o indivíduo entrar na mata para cortar madeira para construir choupanas (uma tarefa bem usual na lida diária dos sertões, e intercalada por diferentes outras atividades complementares); coisa bem diferente (e rejeitada por muitos) era a incursão de um exército de centenas de retirantes adentrando as matas do Cocó, em Fortaleza, para de lá, de manhã até o anoitecer, retirar milhares de galhos de madeira, enfeixados e carregados nos ombros sob os olhares vigilantes de fiscais e feitores (atentos à boa condução dos serviços), e de apontadores (registrando a presença dos operários para que estes obtivessem o direito de receber posteriormente o pagamento pelos serviços prestados).$^{10} \mathrm{O}$ que figurava opressivo aos retirantes eram as atividades das turmas de trabalhadores serem executadas como tarefas massificadas, parceladas, repetitivas e, portanto, desconcertantes a quem tinha por hábito um cotidiano de trabalho mais autônomo e polivalente. Por meio de uma matéria do jornal A Lucta, de Sobral, publicada durante a seca de 1915 e que discutia as condições de trabalho nas obras do açude Patos, percebemos outros aspectos dos constrangimentos derivados dos métodos de trabalho impostos aos operários das secas:

(1877-1919)". (Tese de Doutorado em História Social. Fortaleza: UFC, 2014). A passagem citada nesse parágrafo foi retirada de: Ofício de 8/07/1878, Distritos de Fortaleza, caixa 22, Fundo Socorros Públicos, Arquivo Público do Estado do Ceará (APEC).

10 Ofício de 12/02/1878, Fundo Obras Públicas, APEC. 
Estes pobres homens, mirrados e enfraquecidos por uma fome de dez meses, são ali obrigados diariamente, mediante o parco jornal de $1 \$ 000$ [mil réis], a 10 horas de trabalho insano à picareta, sob o rigor de um sol causticante e sobretudo mal comidos, mal bebidos e mal dormidos. Às 11 horas do dia uma sineta dá o sinal de suspender o serviço começado às 6 horas da manhã, partindo apressado o grupo de trabalhadores, cansados e esbaforidos, à casa do engenheiro a obter um cartão que lhe dá o direito de comprar no fornecedor a dois quilômetros de distância o necessário para preparar a primeira refeição. Esta, como não há tempo de ser feita ao fogo, compõe-se de farinha de mandioca e açúcar mascavo e, antes de o infeliz deglutir o último bocado dessa comida agreste e pouco saudável, a fatídica sineta lá está chamando-o com o sinistro sinal de recomeçar o serviço ao qual eles obedecem com a obediência de um crente, com a resignação de um mártir e marcham sem um gesto de desgosto, sem um movimento de repulsa. ${ }^{11}$

Um fator agravante era o fato de geralmente os retirantes serem levados a cumprir tarefas degradantes ou extremamente perigosas, enfrentando às vezes poderosas forças naturais, com seu enfraquecido corpo inanido por tantas jornadas de subalimentação. De Sobral, por exemplo, algumas turmas de retirantes foram selecionadas durante a seca de 1877 para, na ausência de animais de tração, levarem eles próprios os "carros puxados a homens" carregados com sacas de gêneros alimentícios desde o porto de Acaraú por uma distância de aproximadamente 100 quilômetros, sob o sol inclemente, por estradas quentes e arenosas. Outras turmas em Acaraú passavam os dias imersas nas águas da barra formada pelo encontro do rio com o mar para ali depositarem pesados sacos de barro e fincarem estacas de troncos de carnaúba no serviço de contenção das marés para viabilizar a atracação de embarcações de grande porte. Nesse trabalho havia aqueles que se afogavam por tentar sustentar as pesadas cargas com água pelo pescoço. E o que dizer do serviço dos carregadores de cadáveres que, durante as jornadas da intensa epidemia de varíola, em 1878, tinham de levar os corpos pelas ruas de Fortaleza até o cemitério improvisado da Lagoa Funda, para o que recebiam doses de aguardente, pois a embriaguez era o único estado em que suportavam entrar em contato com os mortos e suas chagas expostas? Sempre que se necessitava fabricar cal ou blocos cerâmicos para as obras de socorros públicos algumas turmas de operários eram obrigadas a expor seus corpos às elevadas temperaturas dos fornos. Finalmente, perigoso também era o manuseio de explosivos usados em diversas obras, principalmente nas aberturas de estradas por trechos pedregosos e íngremes. Uma crônica publicada na revista literária O Pão da Padaria Espiritual registra o caso de um menino traumatizado com o apito do trem que diariamente passava pela frente de seu casebre, em que vivia com sua mãe viúva. Todos os dias, segundo a narrativa, a criança de oito anos derramava lágrimas pelo rosto, "expansão de pesar e ódio de coração infantil"; seu pai, antigo feitor da turma de cavouqueiros, morrera dois anos antes em circunstâncias trágicas, soterrado pelas pedras deslocadas numa das explosões durante as jornadas de construção da estrada de ferro de Baturité. ${ }^{12}$

Em face aos fatores de rejeição ao trabalho, a situação de penúria por que passavam os retirantes famintos tornava-se um dos únicos motivos que os fazia

11 A Lucta, Sobral, 10 nov. 1915.

12 Ofício de 5/12 e 14/12/1877, Sobral, caixa 15, e ofício de 25/07/1889, Acaraú, caixa 1, Fundo Socorros Públicos, APEC. TEÓFILO, Rodolfo. Varíola e vacinação no Ceará. Fortaleza: Oficinas do Jornal do Ceará, 1904, p.13, 27-28. SABOIA, Eduardo. "O trem de ferro". O Pão da Padaria Espiritual, Fortaleza, ano 2, n.12, p.4, edição de $15 / 03 / 1895$. 
aceitar manterem-se nas obras. A mobilidade dos retirantes era um elemento complicador com o qual engenheiros e comissários tinham sempre de lidar para garantir a continuidade das obras de socorros públicos. Ocorre, no entanto, que a falta de comida (a distribuição apenas parcial desta ou o oferecimento de víveres estragados) era um problema estrutural dessas obras. Nos tempos de maior irregularidade no fornecimento dos socorros a evasão tornava-se um desafio para os administradores darem continuidade aos trabalhos. Desdobravam-se em argumentos e promessas para contemporizar e, diante dos olhares indignados dos retirantes, convencê-los de que providências estavam sendo tomadas e que sem muita demora receberiam enfim seus pagamentos... e aplacariam sua fome. Diziam ainda aos retirantes que não encontrariam melhores condições em outras obras, ao mesmo tempo em que se notificava aos governantes sobre as ocorrências, sugerindo que fosse aumentado o controle sobre a emigração por estradas e portos no sentido de tentar inibir a "fuga de braços", para que não faltasse de todo a mão de obra necessária ao regular andamento dos trabalhos. ${ }^{13}$

Revelava-se então a oposição de projetos e expectativas em relação às obras de socorros públicos: enquanto engenheiros e a elite política viam naquelas obras um meio de formação de uma classe de trabalhadores disciplinados e afeitos à modalidade do trabalho assalariado, os retirantes visavam primordialmente a obtenção do socorro. E quando a ração faltava ou estava estragada, a revolta costumava explodir. Num dos ofícios trocados entre o pessoal encarregado pelo funcionamento das comissões de socorros que margeavam a construção da estrada de ferro de Baturité na seca que durou de 1877 até 1879, um encarregado dos depósitos de alimentos alertava as autoridades para a agitação dos operários ao saberem que suas rações seriam reduzidas pela metade. A situação, dizia, "tem motivado surexcitação [sic] entre os trabalhadores desta Estrada, em alguns abarracamentos rompendo eles em ameaças". ${ }^{14}$

As turmas de operários que eram criadas com a intenção original de viabilizar o trabalho segundo os padrões hierárquicos já antes referidos transformavam-se logo em focos de resistência, com os retirantes fazendo de seu grande número um poderoso meio de pressão sobre seus superiores. Além dos saques aos depósitos (que era uma modalidade básica da ação direta dos operários das secas), surgiam as ameaças e os ataques contra engenheiros e comissários, a sabotagem, o corpo mole na execução dos serviços... A violência era enfim incorporada como instrumento nas lutas de classe do cotidiano das obras de socorros públicos. ${ }^{15}$

Sem muitas alternativas de convencimento os administradores das obras armavam homens para impor respeito e conter levantes. Certa vez, na seca de 1919, uma delegação de operários procurou a redação do jornal A Lucta, de Sobral, para denunciar que fiscais das obras de construção do tronco ferroviário entre Sobral e Fortaleza "ali andam ostensivamente armados de revólveres e por qualquer coisa ameaçam o infeliz operário faminto e trucidado com um trabalho forçado". Sendo convocado pelo delegado para prestar esclarecimentos sobre o caso, o engenheiro residente da linha alegou simplesmente que seus homens "fiscalizam trabalho a 10 quilômetros fora da cidade", tentando assim sensibilizar o delegado para o

13 Nota de 31/07/1879, Fundo Estrada de Ferro de Baturité, APEC. As circunstâncias de tensas negociações como essa exposta nesse parágrafo podem ser reconstituídas a partir de diversos ofícios do Fundo Estrada de Ferro de Baturité, APEC, e encontram-se narrada com detalhes em: CÂNDIDO. "Proletários das secas", p.201-207.

14 Ofício de 18/08/1879, Fundo Estrada de Ferro de Baturité, APEC.

15 Sobre as formas de protestos dos retirantes das secas, cf. NEVES, Frederico de Castro. A multidão e a história: saques e outras ações de massa no Ceará. Rio de Janeiro: Relume Dumará, 2000. 
perigo que os supervisores corriam em se encontrarem a sós com os operários descontentes. Numa outra denúncia, dizia-se que os engenheiros da ferrovia de Baturité tratavam os operários "como escravos", exigindo que baixassem o olhar e descobrissem a cabeça ao passarem, em sinal de respeito, e que usavam castigálos com chibateamentos, dependendo da gravidade da falta cometida. ${ }^{16}$

Um registro fotográfico pertencente ao acervo do Museu da Imagem e do Som de Fortaleza mostra uma turma de assentadores de dormentes em plena atividade. Infelizmente não se pôde apurar de qual trecho da ferrovia foi capturado o instantâneo. A imagem mostra os operários trabalhando sob o olhar atento de um supervisor (decerto um engenheiro, situado à direita na foto, em primeiro plano, de terno branco) e uma grande quantidade de curiosos, na maioria mulheres e crianças bem vestidas, protegidas da insolação por suas sombrinhas. Enquanto a maioria dos operários aparece carregando dormentes nos ombros ou debruçados, ajustando o assentamento dos mesmos, alguns homens circulam pelo perímetro entre os trabalhadores e o público. Alguns desses aparentemente carregam algum objeto a tiracolo, talvez uma arma de fogo. Situado à esquerda na foto, em primeiro plano, caminhando, portando chapéu preto e de cabeça abaixada, ali está um deles.

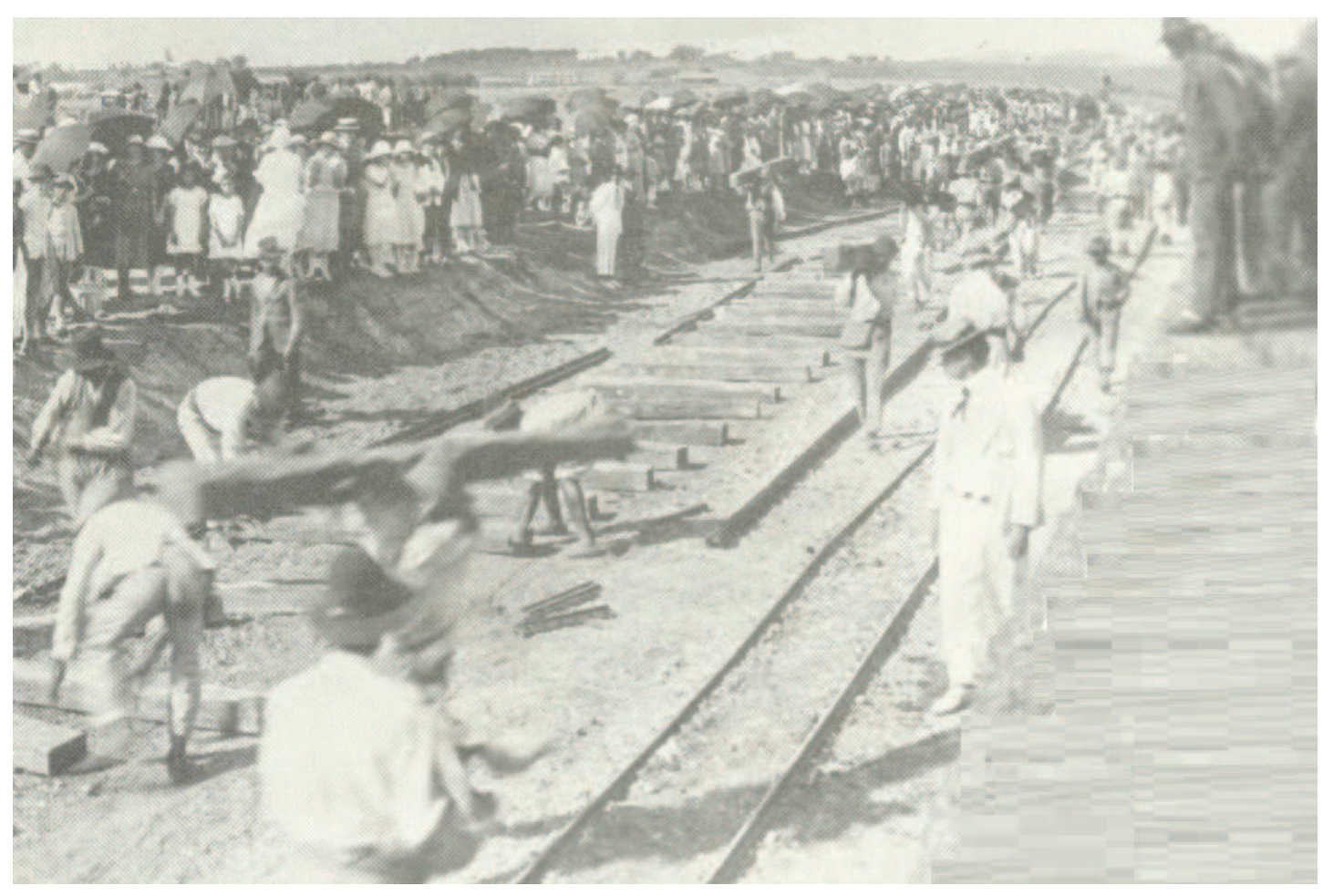

Fonte: Museu da Imagem e do Som, Fortaleza. Sem data definida.

Uma ordem disciplinar imposta de modo rígido e severo era, já por sua vez, fruto de uma determinada percepção que engenheiros e supervisores tinham a respeito dos padrões comportamentais dos sertanejos nas obras de socorros públicos. Julgados como propensos à preguiça, suspeitos de incorrerem em subterfúgios para driblar as regras quanto a horários e postura ordenada, os operários teriam de sentir o peso das punições para que aprendessem a trabalhar de modo regular.

Outro mecanismo um tanto menos ostensivo que a exibição das armas de fogo, mas certamente tomado pelos administradores como bastante eficaz para

16 A Lucta, Sobral, 3 dez. e 10 dez. 1919. Echo do Povo, Fortaleza, 9 jul. 1879. 
convencer os operários das secas a trabalhar em ordem era a retenção de pagamentos visando conter evasões e atos de insubordinação. Denúncias informam que multas pesadas recaíam sobre retirantes por motivos os mais banais: ausência ao trabalho motivada por doenças, pausas para o descanso durante um ou dois minutos ou ainda quando os trabalhadores eram flagrados em brigas. Segundo o jornal Echo do Povo, de Fortaleza, referindo-se aos trabalhos de construção da estrada de ferro de Baturité em 1879:

Aqueles que, trabalhando 26 dias, perdem um por moléstia ou outro motivo perdem metade do salário de todo o mês; outros que, fatigados, sentam-se para descansar um ou dois minutos são multados em metade dos salários e às vezes em todo; outros, finalmente, por tolas altercações que têm entre si, incorrem na mesma multa. ${ }^{17}$

O envolvimento dos operários em dívidas com fornecedores buscava conter a evasão e se constituiu em matéria de contestação durante os tempos de seca. Para os operários, multas e prisões por dívidas não combinavam com o que pensavam ser apropriado para um serviço acionado como recurso de socorro. Pela fala de um pequeno grupo de operários que procurou a redação do jornal $A$ Lucta na seca de 1915 pode-se captar alguns elementos dessa subjetividade de uma gente indignada com as condições de trabalho:

Nós vem do Açude Tucunduba, onde fumos tratados cuma bicho bruto. Aquilo não é lá oxílio pus famintos, é um trumento. A gente ganha $1 \$ 200$ [mil e duzentos réis] pur dia, nos dão um vale de $\$ 950$ [novecentos e cinquenta réis] pra comprá gêneros no fornecedor e os chefes dos serviços fica com o resto pra mode dá no fim do mês. Se a gente não arrisiste o trabaio cuma num arrisistimos e larga o serviço antes do fim do mês num arrecebe nenhum vintém daquele dinheiro que tava na mão do dr., cuma cada um de nós deixou lá um bocadão. ${ }^{18}$

As experiências do trabalho forçado marcaram a vida de gerações de trabalhadores pobres do sertão seco no Norte brasileiro. Numa região de industrialização e urbanização incipientes, os contingentes de sertanejos ocupados nas obras de socorros públicos assumiam dimensões, digamos assim, faraônicas. Na seca de 1877-79, pelos canteiros de obras da estrada de ferro de Baturité, trabalharam algo em torno de cinquenta mil pessoas. Número aproximado também do pessoal ocupado na estrada de ferro de Sobral naquela mesma seca. Para Quixadá, palco da construção do grande açude do Cedro, em 1889, confluiu uma massa de noventa mil pessoas. A cada seca do período, centenas de obras de variadas dimensões absorviam como mão de obra aquelas aglomerações de retirantes tão temidas e rejeitadas pelas cidades sobressaltadas. Como procurei demonstrar em minha tese de doutorado, apesar de provisórios, restritos aos meses de estiagem, os serviços desenvolvidos durante os anos de escassez prolongada foram capazes de formar uma espécie de proletariado das secas, pessoas que, ainda que voltando a sua condição original de trabalhadores rurais em tempos de chuvas regulares, passavam a incluir em seu horizonte de expectativas a possibilidade de ter de trabalhar em alguma obra de socorro público para enfrentar os tempos mais difíceis das secas. ${ }^{19}$

17 Echo do Povo, Fortaleza, 7 ago. 1879

18 A Lucta, Sobral, 12 jan. 1916.

19 CÂNDIDO. "Proletários das secas", p.88-94, 162 e 171. 


\section{Repensando sobre a "transição para o trabalho livre"}

Isso coloca um problema historiográfico de fundo. Para o caso dos proletários das secas, a inserção das relações de trabalho assalariadas não corresponde à narrativa de uma "transição para o trabalho livre". Não porque não se estaria naquela época vivendo um momento de transição no sentido de haver transformações estruturais em curso, mas porque as novas relações de trabalho que surgiam não eram propriamente livres, apesar de os operários em foco não serem tampouco classificáveis como escravos.

"Trabalho escravo" e "trabalho livre" não são, desse modo, as únicas categorias de análise encontráveis para nos referirmos às experiências dos trabalhadores que viveram aquele contexto de transformações. Entre essas modalidades-limites de relações de produção havia diversos outros tipos de trabalho não livre, uns mais "degradantes", outros menos, uns mais "forçados" que outros. As relações estruturadas nas obras de socorros públicos durante as secas da passagem do século XIX revelam diversos aspectos particulares que não devem ser generalizáveis para outros contextos, mas se constituem em índice importante a mostrar como a trajetória histórica para a implantação de relações assalariadas é matéria muito mais complexa e problemática do que se pensava.

Em geral, os estudos históricos no Brasil sobre as mudanças nas relações de trabalho no contexto do fim da escravidão abordaram o processo de implantação de relações capitalistas no país a partir de noções de "trabalho livre" e "trabalho escravo" como realidades plenamente distintas e excludentes. Mais preocupados em estabelecer uma ordem classificatória que observar o processo a partir das experiências mesmas vivenciadas por patrões e trabalhadores, historiadores e cientistas sociais abordaram o processo da "transição para o trabalho livre" balizados por uma visão da expansão do capitalismo como constituindo uma espécie de via de mão única, visão essa muito pouco aberta para incorporar retrocessos, ambiguidades ou contradições. Apesar dos variados pontos de vista e procedimentos de análise, nomes importantes do pensamento social brasileiro confluíam para a tese de ter havido durante a passagem do século XIX uma grande transformação em que o trabalho livre teria ocupado o lugar deixado pelo trabalho cativo, extinto com a Abolição em 1888. Mesmo José de Souza Martins, que ressaltava a persistência (e ainda a intensificação) de formas de acumulação pré-capitalistas no processo de declínio do escravismo e implantação do regime de colonato nas zonas cafeicultoras do país, ainda falava em termos de uma "substituição do trabalho escravo pelo livre". ${ }^{20}$

Decerto, uma das dificuldades dos modelos explicativos sobre o assunto está relacionada à tese marxiana de que havia uma única maneira "verdadeiramente" capitalista de tornar a força de trabalho uma mercadoria vendável, assalariável: aquela em que o trabalhador, "como indivíduo livre, pode dispor de sua força de trabalho como uma mercadoria que lhe pertence". Marx foi mesmo convincente quando demonstrou o quiproquó que essa tal "liberdade" do trabalhador assalariado

20 Apesar de diferentes em termos de abordagem do problema pode-se relacionar como trabalhos que compartilham da ideia de que a transição representou a substituição do trabalho escravo pelo trabalho livre: PRADO JR. Caio. História econômica do Brasil. $17^{\text {a }}$ ed. São Paulo: Brasiliense, 1974. FURTADO, Celso. Formação econômica do Brasil. São Paulo: Companhia das Letras, 2007. FERNANDES, Florestan. A integração do negro na sociedade de classes. $2^{a}$ ed. São Paulo: Ática, 1978. COSTA, Emilia Viotti da. Da monarquia à república: momentos decisivos. $3^{\text {a }}$ ed. São Paulo: Editora Brasiliense, 1985. MARTINS, José de Souza. O cativeiro da terra. São Paulo: Liv. Ed. Ciências Humanas, 1979. 
representa, pois sendo "livre num duplo sentido", gozava da liberdade de todo cidadão juridicamente emancipado ao mesmo tempo em que era "livre dos meios de produção", ou seja, não podia dispor dos meios de vida, sendo obrigado a se assalariar para sobreviver. Sobre essa natureza contraditória de um modo de produção que mascara a servidão moderna sob o manto do livre comércio de mercadorias - pois afinal o assalariado é mesmo livre para vender sua capacidade de trabalho a quem quer que se disponha a comprá-la - Karl Marx concentrou a maior parte de sua obra. Para chamar a atenção a essa ambiguidade da liberdade sob as relações assalariadas, Friedrich Engels, que buscava ser sempre mais didático que Marx (sendo algumas vezes menos criterioso), usava a expressão "escravidão assalariada". ${ }^{21}$

O que torna problemática a tese de Marx de haver uma única via verdadeiramente capitalista de implantação do trabalho assalariado é a predisposição que tal postura teórica comporta de excluir do horizonte histórico formas alternativas de trabalho compulsório que não se enquadrem nas características dos modelos clássicos de trabalho escravo ou trabalho livre. Decerto, Marx mostrou com toda a propriedade o caráter opressivo do trabalho livre e revelou, em O capital, os segredos internos da exploração assalariada. No entanto, sua opção declarada por privilegiar exemplos da sociedade inglesa, por ser esse país a "localização clássica" a servir "de ilustração principal à minha explanação teórica", ${ }^{22}$ levou Marx a desconsiderar outros modos de expansão do capitalismo.

E não se trata aqui tão somente de um prejuízo de ordem teórica. Ao falar no "desenvolvimento dos antagonismos sociais que decorrem das leis naturais da produção capitalista" como uma "necessidade férrea", Marx permitiu de certa maneira que sua exposição histórica se aproximasse dos discursos liberais prevalecentes em sua época que, ao exaltar os valores positivos do trabalho livre, buscavam ao mesmo tempo naturalizar o surgimento da sociedade de mercado e, com ela, a própria formação do mercado de trabalho. Nessa visão triunfalista da sociedade capitalista, o assalariamento figurava antes como uma questão de opção disponível para o trabalhador que uma obrigação compulsória de dispêndio de sua força de trabalho. ${ }^{23}$

A passagem do século XIX, no entanto, testemunhava aos quatro cantos do mundo o surgimento de novas relações de trabalho forçado, como que a desmentir de facto as ilusões triunfalistas liberais. A entrada do capitalismo em uma nova fase de expansão por volta de meados do século XIX gerou um reordenamento do controle econômico sobre novos territórios até então apenas indiretamente conectados com as bases industriais do sistema. Segundo Eric Wolf, "regiões que se situavam ao longo da orla da expansão capitalista ou entre seus postos mais avançados" começaram a serem incorporadas mais diretamente pela produção fabril das zonas industriais europeias como novos fornecedores de matérias-primas e de mão de obra. Rosa Luxemburgo, que por essa época abordou "a questão

21 MARX, Karl. O capital: crítica da economia política, v.1, t.2. São Paulo: Abril Cultural, 1984, principalmente o capítulo V: "O processo de trabalho e o processo de valorização", p. 149-163. Lê-se em: ENGELS, Friedrich. A situação da classe trabalhadora na Inglaterra. São Paulo: Boitempo, 2010, p. 118: "Eis por que o proletariado, de direito e de fato, é escravo da burguesia, que dispõe sobre ele de um poder de vida e de morte. Ela Ihe oferece os meios de subsistência, mas em troca de um 'equivalente' - seu trabalho; e chega ao ponto de lhe dar a aparência de agir segundo sua própria vontade, de estabelecer livremente com ela um contrato, sem constrangimentos, como se o proletariado fosse o autor de seu próprio destino. Bela liberdade, que deixa ao proletariado, como alternativa à aceitação das condições impostas pela burguesia, a chance de morrer de fome, de frio, de deitar-se nu e dormir como animal selvagem!"

22 MARX. O capital, p.12.

23 Vão nessa direção as objeções levantadas por WOOD, Ellen Meiksins. A origem do capitalismo. Rio de Janeiro: Jorge Zahar Ed., 2001. 
da proveniência desse proletariado urbano e rural que aflui constantemente" dos países não europeus, "passando de condições não capitalistas para capitalistas", explicou da seguinte forma o problema:

Assim como a produção capitalista não pode limitar-se às riquezas na-
turais e às forças produtivas das zonas temperadas, necessitando para
seu desenvolvimento, pelo contrário, de todos os tipos de terra e de
clima, da mesma forma só a força de trabalho da raça branca não lhe
basta. Para o aproveitamento de regiões em que a raça branca não tem
condições de trabalhar, o capital necessita de outras raças. Tem de po-
der dispor de forma ilimitada de toda a força de trabalho do globo in-
teiro, para com ela pôr em movimento todas as forças produtivas da
face da Terra, na medida em que os limites da produção da mais valia
o permitam. Essa força de trabalho o capital encontra, no entanto, ge-
ralmente presa a condições de produção arcaicas, pré-capitalistas, das
quais precisa ser previamente "libertada", para que possa engajar-se no
exército ativo do capital. ${ }^{24}$

Essa "libertação" das "condições de produção arcaicas e pré-capitalistas" significava concretamente que governos e empresários por todo o planeta lançavam mão de métodos compulsórios para obrigar pessoas infensas ao trabalho assalariado a "engajar-se no exército ativo do capital". Ainda sentiam-se os efeitos da ressaca deixada pelas comemorações pela abolição oficial do trabalho escravo nos países ocidentais durante os Oitocentos, e já uma nova onda de trabalho compulsório alastrava-se pelo mundo.

Raphael Samuel, dedicando-se a mostrar os impactos trazidos pelas máquinas a vapor sobre as condições de trabalho na Inglaterra vitoriana, constatou que, longe de terem sido instrumentos para a libertação da energia humana, as modernas indústrias mecanizadas geraram novos patamares de produção que implicaram em ainda maior intensificação da exploração sobre a maioria dos trabalhadores, e isso não só no seio da "grande oficina do mundo". Em suas palavras: "A revolução industrial, longe de reduzir o trabalho humano, criou todo um novo mundo de empregos de trabalho pesado: a construção de ferrovias é um primeiro exemplo". O século XIX teria, desse modo, testemunhado "uma enorme deterioração nas condições de trabalho". Essa relação entre mecanização e a intensificação do trabalho não se deu de modo homogêneo e em todo o lugar. Bem pelo contrário:

O capitalismo no século XIX desenvolveu-se em vários sentidos. A mecanização num departamento de produção foi sempre complementada por um incremento de trabalho pesado em outros; o crescimento de grandes firmas pela proliferação de pequenas unidades de produção; a concentração de produção em fábricas pela difusão do trabalho doméstico por encomenda. ${ }^{25}$

No meio dessas conexões contrastantes, muitos construtores de estradas, canais e ferrovias pelo mundo continuavam a exercer seu trabalho usando suas convencionais picaretas e pás (pick-and-shovel works), a despeito de todos os avanços verificados na engenharia civil. Mas a extensão crescente de vias de

24 WOLF, Eric R. A Europa e os povos sem história. São Paulo: Editora da Universidade de São Paulo, 2005, p.369. LUXEMBURGO, Rosa. A acumulação do capital: contribuições ao estudo econômico do imperialismo. $2^{a}$ ed. São Paulo: Nova Cultura, col. Os Economistas, 1985, p.248-249.

25 SAMUEL, Raphael. Workshop of the world: steam power and hand technology in mid-Victorian Britain. History Workshop Review, London, n.3, p.8, 13 e 17, spring 1977. 
comunicação pelo planeta fazia com que um número muito maior de pessoas engrossasse os exércitos desse ramo de trabalho pesado. Ao contrário do que era festejado nas Exposições Universais da época, o progresso da grande indústria e das relações comerciais pelo mundo não apenas não implicava na emancipação das maiorias pelo planeta como contribuía para agrilhoar os trabalhadores com ainda mais servidão e trabalho pesado.

Verifica-se desse modo a importância de se observar com maior cuidado as relações de trabalho compulsório, forçado, porém não "escravo" no contexto de expansão do capitalismo. A emergência de uma perspectiva global na história social do trabalho contribui sobremaneira nesse sentido, na medida em que apresenta múltiplos exemplos de métodos coercitivos de trabalho em contextos em que os trabalhadores não eram eles mesmos uma propriedade de seus senhores (ou seja, não eram escravos). Marcel van der Linden, em obra recentemente publicada no Brasil, propõe alternativas de análise a uma visão eurocêntrica e assegura que, "na realidade, a mercantilização da mão de obra toma muitas formas diferentes, entre as quais a forma em que o trabalhador livre vende unicamente sua força de trabalho é apenas um exemplo". ${ }^{26}$ Apresenta nesse sentido abundantes casos em que o trabalho assalariado esteve associado a métodos coercitivos como a servidão por dívida ("ocorreu em todos os continentes, das minas de carvão da Escócia do século XVIII ao setor agrícola contemporâneo da América Latina e do sul da Ásia”), a servidão por contrato (os "coolies indianos, indonésios e chineses empregados na África do Sul, na América Latina e em outras partes da Ásia”), a compulsão física para impedir a saída dos trabalhadores (na "indústria têxtil japonesa da década de 1920, trabalhadoras eram trancadas em dormitórios por essa exata razão"), a dependência programada com a criação de fundos de ajuda mútua ou hortas coletivas oferecidas pela empresa. ${ }^{27}$

Assim sendo, o postulado de uma "transição para o trabalho livre" tende a ser crescentemente contestado por historiadores sociais do trabalho. No Brasil, a aproximação progressiva entre os estudos da escravidão e da história do trabalho (até um tempo atrás visto como campos de investigação separados) tem se dado através da evidenciação de experiências compartilhadas tanto por escravos quanto por trabalhadores livres. Novas pesquisas revelam que nem a escravidão foi um problema exclusivo de africanos trazidos como cativos e seus descendentes, como também a organização de classe, com suas greves e outros métodos de luta, não foram frutos exclusivos das ações de trabalhadores livres. ${ }^{28}$

A persistência de características de trabalho não livre no contexto da pósabolição ou, quando ainda nos tempos do cativeiro, nas experiências de libertos ou pobres livres (sujeitos sociais, nesse sentido, juridicamente emancipados) tornou-se um tema historiográfico de crescente interesse entre os historiadores sociais. Discute-se cada vez mais sobre a precariedade da liberdade na vida dos pobres que viveram a passagem do século XIX e um novo foco concentra-se nas chamadas relações de "trabalho análogo ao de escravo" em contextos mais recentes. ${ }^{29}$

26 LINDEN, Marcel van der. Trabalhadores do mundo: ensaios para uma história global do trabalho. Campinas: Unicamp, 2013, p. 29.

27 LINDEN. Trabalhadores do mundo, p. 32-33.

28 A discussão se apresenta em: LARA, Silvia Humbold. "Escravidão, cidadania e história do trabalho no Brasil. Revista Projeto História, São Paulo, n. 16, p. 25-38, fev. 1998. MATTOS, Marcelo Badaró. "Trabalhadores escravizados e livres na cidade do Rio de Janeiro na segunda metade do século XIX”. Revista Rio de Janeiro, n. 12, p. 229-251, 2004. NEGRO, Antonio Luigi \& GOMES, Flávio dos Santos. "Além das senzalas e das fábricas: uma história social do trabalho". Revista Tempo Social, v. 18, n. 1, p. 217-240, 2006.

29 LIMA, Henrique Espada. "Sob o domínio da precariedade: escravidão e os significados da liberdade no 
Ainda é desafiante a desproporção na história social do trabalho entre as investigações que abordam as composições de trabalhadores situados nos principais centros urbanos e industriais do país (sem sombra de dúvida, uma parte importante dos trabalhadores, tanto pelo lugar social que ocupavam quanto pela visibilidade que seu fazer-se de classe lhes proporcionou, mas ainda assim uma minoria da população laboriosa durante o período aqui discutido) em relação às pesquisas que elegeram tratar dos grupos de trabalhadores dispersos pelas extensas regiões do interior do país, territórios heterogêneos de comunidades indígenas, quilombolas, caboclas, de sertanejos ou de estrangeiros recém-chegados (sendo essas fronteiras econômicas do país as zonas em que mais se apresentam casos de trabalho forçado). A questão da invisibilidade historiográfica continua sendo um problema para essas maiorias trabalhadoras que viveram no relativo isolamento das matas, fazendas e minas, e isso a despeito do crescente interesse de historiadores por esses sujeitos. ${ }^{30}$ É bem possível que, na medida em que novos estudos venham a produzir maiores evidências sobre as características das atividades exercidas por seringueiros, castanheiros, colhedores de erva-mate, café, cacau, trabalhadores de colônias agrícolas e militares, soldados aquartelados em zonas de fronteiras, carreteiros, regatões, entre tantos outros personagens coletivos, um quadro bem diverso sobre as condições de trabalho no Brasil da passagem do século XIX se revele.

Enfim, resta ainda o embaraço de não haver qualquer consenso acerca da definição do que se entende por "trabalho forçado". Sequer uma denominação comum é hoje capaz de contemplar as muitas e diversificadas problemáticas levantadas por historiadores, sociólogos, geógrafos, juristas, assistentes sociais, militantes. Fala-se como termos mais ou menos intercambiáveis em trabalho compulsório, trabalho forçado, trabalho degradante, escravidão contemporânea, trabalho análogo ao de escravo..., mas uma aproximação decisiva a respeito de uma categoria e entendimento compartilhados parece ser uma situação que ainda está longe de ser alcançada. ${ }^{31}$

Certamente a dificuldade deriva de alguma maneira do mal-estar que os aspectos degradantes do trabalho forçado provocam nas consciências dos que fazem a civilização, pois aí se revela uma contradição embaraçosa de nossa própria condição humana. A cada notícia publicada pelos jornais, informando sobre pessoas mantidas em condições indignas, sem acesso à alimentação adequada, dormindo

século XIX”. Topoi, Rio de Janeiro, vol. 6, n. 11, p. 289-325, 2005. CHALHOUB, Sidney. A força da escravidão: ilegalidade e costume no Brasil oitocentista. São Paulo: Companhia das Letras, 2012. GOMES, Ângela de Castro. "Repressão e mudanças no trabalho análogo ao de escravo no Brasil: tempo presente e usos do passado”. Revista Brasileira de História, Rio de Janeiro, v. 32, p. 167-184, 2012. GUIMARÃES NETO, Regina Beatriz. "Violência e trabalho na Amazônia: narrativa historiográfica". Revista Territórios e Fronteiras, Cuiabá, v.7, n.1, p.27-46, abr. 2004.

30 São de meu conhecimento: CORMINEIRO, Olivia M. "Percepções do tempo e trabalho: as disputas dos sertanejos pobres no extremo norte de Goiás em torno de seus modos de viver - 1860-1920". Revista Mundos do Trabalho, v.1, n.2, p.171-194, 2009. BORGES, Ana Carolina da Silva. "Os 'ribeirinhos' do Pantanal Norte: temporalidades, práticas rurais e cotidiano. Revista Mundos do Trabalho, v.2, n.4, p.305-335, 2010. FULLER, Cláudia Maria. "Os Corpos de Trabalhadores e a organização do trabalho livre na província do Pará (18381859). Revista Mundos do Trabalho, v.3, n.6, p.52-66, 2011. WOLFF, Cristina Scheibe. "Mulheres da Floresta: outras tantas histórias". Revista Estudos Amazônicos, v.VI, n.1, p.21-40, 2011. PAZ, Adalberto. "Caboclos, extrativistas e operários: a formação da mão de obra industrial na Amazônia nos anos 1940". Revista Mundos do Trabalho, v.5, n.9, p.171-187, 2013. CORMINEIRO, Olívia M. \& MEDEIROS, Euclides Antunes. "O universo dos trabalhadores dos castanhais: cotidiano e exploração no Vale do Tocantins (1890-1940)". Revista Mundos do Trabalho, v.5, n.9, p.283-305, 2013. LIMA, Frederico de Oliveira. "De Arigó a Soldado da Borracha e o fazer-se do seringueiro na Amazônia”. Revista Tempo Amazônico, v.2, n.1, p.4-24, jun./dez. 2014.

31 FERRERAS, Norberto O. \& SECRETO, María Verónica. Os pobres e a política: história e movimentos sociais na América Latina. Rio de Janeiro: Mauad X/FAPERJ, 2013, p.69-94. 
sem as mínimas condições de conforto ou higiene, correndo risco de perder sua própria existência por executar um trabalho pessimamente remunerado (quando tanto), tendo sido usurpado do próprio direito de poder procurar em algum outro lugar uma alternativa de vida melhor, somos levados a nos questionar (uma vez mais) sobre o significado de nossa própria liberdade. Mas, ainda que embaraçoso, o problema não deixa de ser real. Retirantes das secas, há mais de um século, já faziam a denúncia.

Recebido em 22/12/2015

Aprovado em 03/11/2016 